\title{
Lipofuscin-Like Pigments in the Rat Heart During Early Postnatal Development: Effect of Selenium Supplementation
}

\author{
I. OŠŤÁDALOVÁ ${ }^{1,2}$, Z. CHARVÁTOVÁ ${ }^{1,2}$, J. WILHELM ${ }^{1,3}$
}

${ }^{1}$ Center for Experimental Cardiovascular Research, Prague, Czech Republic, ${ }^{2}$ Institute of Physiology, Academy of Sciences of the Czech Republic, Prague, Czech Republic, ${ }^{3}$ Department of Medical Chemistry and Biochemistry, Second Faculty of Medicine, Charles University, Prague, Czech Republic

Received November 23, 2009

Accepted March 18, 2010

On-line June 9, 2010

\section{Summary}

The aim of the study was to characterize a) the lipofuscin-like pigment (LFP) accumulation (an indicator of ROS production) in the rat heart during early postnatal period and b) possible antioxidative role of selenium. Experimental animals received $\mathrm{Na}_{2} \mathrm{SeO}_{3}$ in drinking water during gravidity and up to day 15 post partum. Two fluorophores of LFP in the hearts of 1-, 4-, 7- and 15 -day-old rats were evaluated by fluorescent analysis. The highest level of heart/body weight ratio in control rats was observed on day 4, in the Se-supplemented rats on day 7. Cardiac LFP content in controls increased from postnatal day 4 , in the hearts of Se-supplemented rats the LFP content increased already from day 1 . As compared with the Se-supplemented group the LFP content of control hearts was significantly higher on day 1 but significantly lower on day 4. LFP concentration in control hearts decreased from postnatal day 1 to 4 ; this decrease was followed by significant increase until day 7 and decrease to day 15. LFP concentration in the Se-supplemented hearts was the highest on postnatal day 7; it differed from controls on day 1 and 4. Significant changes of LFP suggest an important role of ROS during critical ontogenetic period.

\section{Key words}

Early postnatal development • Heart • Lipofuscin-like pigment • Selenium • Radical oxygen species

\section{Corresponding author}

I. Oštádalová, Department of Developmental Cardiology, Institute of Physiology, Academy of Sciences of the Czech Republic, Vídeňská 1083, 14220 Prague 4, Czech Republic. E-mail: iostadal@biomed.cas.cz

\section{Introduction}

Physiological mitochondrial respiration is closely associated with a side-effect - inevitable electron leak. Mitochondria are, therefore, the main site of ROS (reactive oxygen species) formation and also the main target of their attack (Del Roso et al. 1991, Brunk and Terman 2002a). This is also a reason why many mitochondria undergo structural disorganization with decreased ATP production (Brunk and Terman 2002b). ROS continuously cause macromolecular damage despite the normally functioning cellular antioxidant system (Brunk and Terman 2002a). Typical effect of ROS attack is the cross-linking of proteins and other biomolecules; the consequence is probably the nondegradability of autophagocytized material. This material - lipofuscin like pigments (LFP) - is autofluorescent and becomes a source of lipofuscin production in the lysosomes. The presence of LFP is used as an indicator of oxidative damage in biological systems. ROS production influences redox environment in the cell and it is decisive for LFP formation (Sohal et al. 1989, Marzabadi et al. 1991). Data on the ontogenetic development of this process in the rat heart are, however, very scarce and inconsistent. Ikeda et al. (1985), Muscari (1990) and Del Roso et al. (1991) observed higher accumulation of LFP in the rat heart during older periods of postnatal development. On the other hand, Csallany et al. (1981, 1986) described a higher level of LFP in the hearts of weanling rats as compared with 19-month-old rats. Information on the 
early postnatal development of LFP in the heart is not yet available.

It was found that the antioxidative effect of vitamin E (Blackett and Hall 1981) and selenium (Okamoto et al. 1999) can influence ROS generation and consequently LFP accumulation (Gao et al. 1994) in some peripheral tissues of the old rats (Alho et al. 1989) and growing pigs (de Gritz et al. 1994). Data on the effect of selenium on the LFP level in the myocardium during the early postnatal period are, however, lacking.

The aim of the present study was, therefore, to characterize the development of LFP accumulation in the rat heart during the early postnatal period and to analyze possible influence of Se supplementation.

\section{Methods}

\section{Animal model}

The study was conducted in accordance with the Guide for the Care and Use of Laboratory Animals published by the US National Institutes of Health (NIH publication No. 85-23, revised 1996).

A total of six pregnant female Wistar rats were used throughout the experiments. They had free access to water and standard laboratory diet (ST 1 Bergman, $237 \mu \mathrm{g} \mathrm{Se} / \mathrm{kg}$ diet). From day 1 after conception to day 15 post partum the experimental group of pregnant rats (Se, $\mathrm{n}=3$ ) was supplemented by additional amount of selenium (2 ppm $\mathrm{Na}_{2} \mathrm{SeO}_{3}$, Merck) in drinking water, the control group $(\mathrm{C}, \mathrm{n}=3)$ remained without treatment (Oštádalová et al. 2007). The offsprings (a total of 60 neonates) of both sexes were investigated on day 1, 4, 7 and 15 of postnatal life. All animals were weighed and killed by cervical dislocation. Each experimental group of neonates $(n=8)$ was composed of at least three different nests. After killing the animals by cervical dislocation, the chest was quickly opened, the heart was rapidly excised, the atria were removed and the ventricles were weighed, frozen and used for analysis.

\section{Fluorescence analysis}

The technique developed in our laboratory was used for the analysis of LFP (Wilhelm and Herget 1999); it is based on the original method of Goldstein and McDonagh (1976). Briefly, about $50 \mathrm{mg}$ of preweighed, minced, frozen heart was added to $4 \mathrm{ml}$ of chloroform-methanol mixture $(2: 1, \mathrm{v} / \mathrm{v})$ and extracted for one hour on a motor-driven shaker. After extraction, $1 \mathrm{ml}$ of distilled water was added, mixed, and the

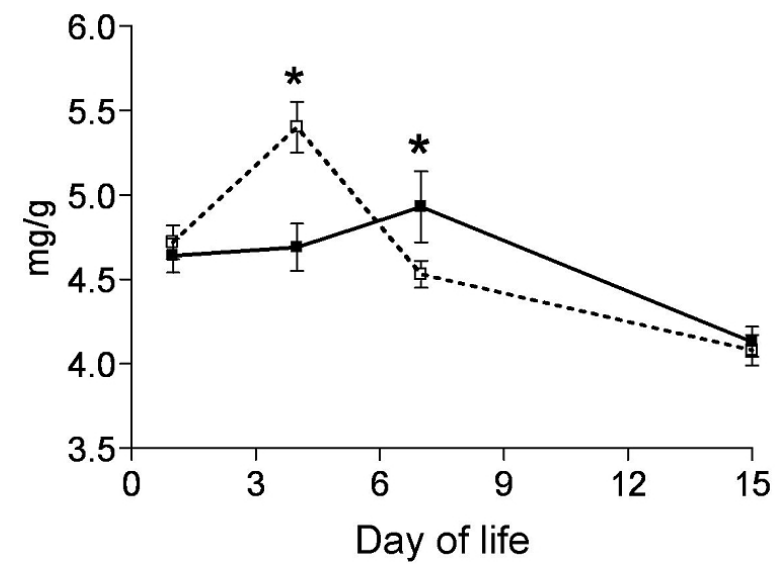

Fig. 1. Development of relative heart weight (heart/body weight, expressed as $\mathrm{mg} / \mathrm{g}$ ) during the early postnatal period of control (dotted line) and Se-supplemented rats (full line). Values are means \pm S.E.M., $*$ significant difference between the groups $(p<0.05)$.

mixture was centrifuged (400 g, $10 \mathrm{~min})$. After centrifugation, the lower chloroform phase was separated and used for measurements. Threedimensional fluorescence spectra were measured on the spectrofluorometer Aminco Bowman series 2 (ChromSpec company, Prague). The excitation spectra were measured in the range of $250-400 \mathrm{~nm}$ for emission wavelengths adjusted between $350-500 \mathrm{~nm}$. The quantitative estimation of LFP was based on the excitation and emission maxima found in 3D spectral arrays. At this estimation two prominent fluorophores with fluorescence characteristics of $355 / 440 \mathrm{~nm}$ and $315 / 450 \mathrm{~nm}$ (excitation/emission) were observed and evaluated during neonatal period. The fluorometer was calibrated with standard No. 5 of the instrument manufacturer and the LFP concentration was expressed in relative fluorescence units per $\mathrm{mg}$ of the tissue wet weight. For the study of changes in the composition of LFP synchronous fluorescence spectra in the range of 300-500 nm were used with constant difference between excitation and emission of 25 or $50 \mathrm{~nm}$.

\section{Statistical analysis}

The results are expressed as means \pm S.E.M. Each observation was obtained from at least six heart preparations in the group. Differences among the groups were evaluated using two- and one-way analysis of variance. For pair wise mean comparisons, the StudentNewman-Keuls multiple range test was applied. All the used programs belong to BMDP Statistical Software, University of California. Differences were considered as statistically significant when $\mathrm{p}<0.05$. 

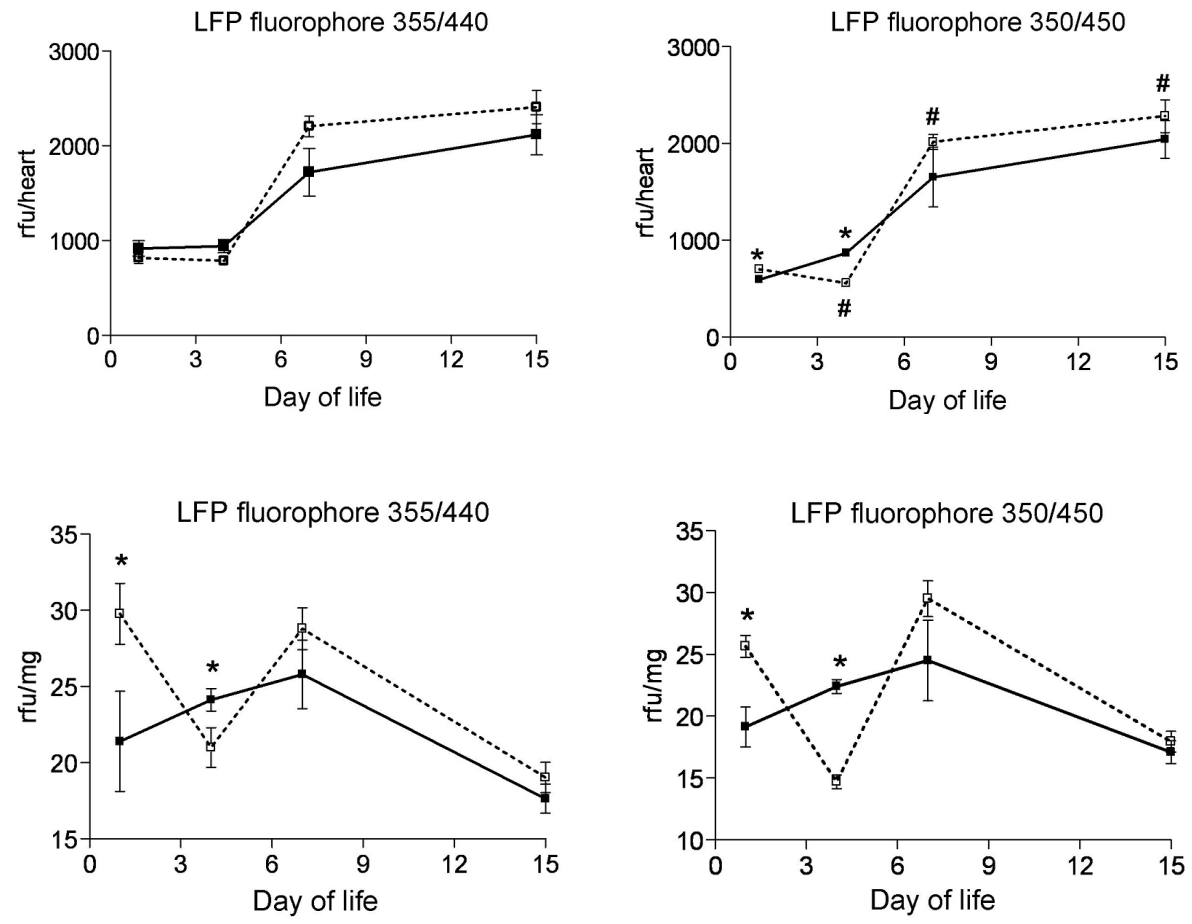

Fig. 2. Development of LFP content (expressed in rfu) in the hearts of control (dotted line) and Sesupplemented (full line) rats during the early postnatal period. Values are means \pm S.E.M., * significant difference between the groups, \# significantly different vs. day 1 $(p<0.05)$.

Fig. 3. Development of LFP concentration (expressed in $\mathrm{rfu} / \mathrm{mg}$ of the heart) in the hearts of control (dotted line) and Se-supplemented (full line) rats during the early postnatal period. Values are means \pm S.E.M., * significant difference between the groups $(p<0.05)$.

\section{Results}

\section{Relative heart weight}

The highest level of heart/body weight ratio in control rats was observed on day 4 , whereas in the group of Se-supplemented rats on day 7 (Fig. 1).

\section{LFP content}

Cardiac LFP content in both groups for fluorophore 355/440 did not change between day 1 and 4, in the controls at fluorophore 350/450 it even decreased. At the older age, control LFP values at both fluorophores markedly increased to day 7 , slow increase was observed to day 15 . The LFP content at fluorophore $355 / 440$ in the hearts of the Se-supplemented group increased from day 4 up to day 15, at fluorophore 350/450 the content increased entire period. On day 1, the LFP content of control hearts was significantly higher and on day 4 significantly lower in comparison with the Se-supplemented group (Fig. 2).

\section{LFP concentration}

LFP concentration in control hearts at both fluorophores was higher on day 1 as compared with Se-supplemented rats; the decrease on day 4 was followed by significant increase to day 7; finally, the concentration decreased to day 15. The values of LFP concentration in the hearts of the Se-supplemented group were similar for both fluorophores, but different from the control values; on day 1 the LFP concentration was lower; it increased until day 7 and returned to the newborn values on day 15. Significant differences between groups were observed on day 1 and 4 (Fig. 3).

\section{Discussion}

The major finding of this study is the characteristic development of LFP concentration in the heart during the suckling period, i.e. during the first 15 days of postnatal ontogeny (Babický et al. 1970). The relatively high values just after birth are followed by a steep decrease to day 4, return to the neonatal values on day 7 and significant decrease to day 15 .

LFP develop mainly as the products of ROSinduced damage of proteins. The destruction of proteins is an important component of a non-stop life-sustaining renewal process to enable repair of essential end-products (Terman and Brunk 2005a,b). To explain this developmental oscillation of LFP concentration during the first days after birth in controls is, however, not easy. The high value of LFP on the first day may reflect the increased protein damage, upregulated by the developmental changes of ROS production. At birth, the mammalian heart meets suddenly with an extremely high ROS concentration as a consequence of the dramatic changes of the living conditions during delivery because barometric pressure increases more than 3 times (from 226 to $760 \mathrm{~mm} \mathrm{Hg}$ ), $\mathrm{PO}_{2}$ in the air increases more than 
3 times (from 47 to $160 \mathrm{~mm} \mathrm{Hg}$ ) and arterial $\mathrm{O}_{2}$ saturation increases even more than 5 times (from 18 to $97 \%$ ). This physiological transition is accompanied by the appropriate change of nutrition: trans-placental supply is interrupted and mother milk nutrition is not yet fully developed (Kuma et al. 2004). These circumstances indicate that ROS production is high on the first day after birth. The neonatal heart can probably use the high ROS concentration for the upregulation of protein degradation which permits production of amino acids, necessary for the maintenance of energy homeostasis during neonatal starvation (Kuma et al. 2004, Komatsu et al. 2005, Mühlfeld et al. 2005).

The decrease of LFP on the fourth day likely reflects cardiac adaptation to postnatal living conditions. It seems that this particular day is a very important turning point in the rat postnatal myocardial remodeling, as follows from the following observations; (a) cellular proliferation (hyperplasia) in rat heart is replaced by hypertrophic growth (Li et al. 1996); (b) the cardiac level of UCP2 and UCP3 is the lowest (Škárka et al. 2003); (c) the value of heart/body weight ratio is significantly increased (Ošt’ádal et al. 1967, Ošt'ádalová et al. 1993); (d) the index of contractility of the hearts during early postnatal period was the lowest (Ošt’ádalová et al. 1993), and e) the cardiac sensitivity to the increasing concentration of $\mathrm{Ca}^{2+}$ is the highest (Oštádalová et al. 1993). It seems, therefore, that day 4 is critical for the postnatal cardiac development in the rat. The LFP concentration in the cardiomyocytes increases to day 7 . During this time cellular proliferation progressively decreases and the cardiac hemodynamic parameters are approaching the adult values (blood pressure, heart rate) (Banerjee et al. 2007). This period is characterized by intensive body growth with daily body weight increments (Babický et al. 1972).

On day 15, LFP again declines, ROS production decreases and redox balance is established. The reasons for these changes are, unfortunately, not known. For the explanation of this development, the changes in cardiac cellular profile have to be taken into consideration. Starting from the birth to day 15, cardiac fibroblast population increased (from $\sim 30 \%$ to $\sim 62 \%$ ) and, on the other hand, the proportion of myocyte population decreased (from $\sim 62 \%$ to $\sim 30 \%$ ) (Banerjee et al. 2007). Furthermore, body growth starts to be retarded because mother milk supplementation (intake calories and water) is inadequate; this is the reason why the young begin to accept available standard laboratory diet (Babický et al. 1972). This day represents, therefore, another crucial point of the early postnatal life: the suckling period terminates, i.e. absolute dependence on the mother is finished and the weaning period starts.

Our observation revealed that supplementation with selenium significantly influenced the content and the concentration of LFP during the first week of life. Selenium is present in the active site of glutathione peroxidase as a key antioxidant enzyme determining the reduction potential for the GSSG/GSH couple. Depending on the total concentration of GSH in a cell, the magnitude of an oxidative event is associated with cellular proliferation, differentiation and death (Schafer and Buettner 2001). Thus selenium is an essential trace element that can operate in the tissue as an oxidative or antioxidative agent in dependence on the state of ROS production and redox balance, and, consequently, LFP concentration. This is probably also the reason why selenium can decrease the high level of ROS and LFP generation, as well as increase the low level of ROS and LFP generation. Selenium at the concentration used thus can counterbalance the ROS concentrations. The impact of the effect of selenium on heart growth during early development after birth is not known. It is interesting to mention that the peak of heart/body weight ratio, a relatively constant parameter for day 4 (Oštádal et al. 1967, Ošt'ádalová et al. 1993), is shifted in the Sesupplemented hearts to day 7.

In conclusion, LFP, as the end-products of oxidative damage, exhibit marked changes during early ontogenetic development and suggest an important role of ROS production during this critical ontogenetic period. ROS represent an important component of the dramatic morphological and physiological changes of the neonatal rat heart.

\section{Conflict of Interest}

There is no conflict of interest.

\section{Acknowledgements}

This study was supported by grant of MSMT 1M0510, and grant AVOZ 50110509. 


\section{References}

ALHO H, KOISTINAHO J, LAAKSONEN HM, HERVONEN A: Effect of lifelong selenium and vitamin E deficiency or supplementation on pigment accumulation in rat peripheral tissues. Adv Exp Med Biol 266: 155-156, 1989.

BABICKÝ A, OŠŤÁDALOVÁ I, PǍ̌ÍZEK J, KOLÁŘ J, BÍBR B: Use of radioisotope techniques for determining the weaning period in experimental period. Physiol Bohemoslov 19: 457-467, 1970.

BABICKÝ A, PAŘİZK J, OŠŤÁDALOVÁ I, KOLÁŘ J: Initial solid food intake and growth of young rats in nests of different size. Physiol Bohemoslov 22: 557-566, 1972.

BANERJEE I, FUSELER JW, PRICE RL, BORG TK, BAUDINO TA: Determination of cell types and numbers during cardiac development in the neonatal and adult rat and mouse. Am J Physiol 293: H1883-H1891, 2007.

BLACKETT AD, HALL DA: Tissue vitamin E and lipofuscin accumulation with age in the mouse. J Gerontol 36: 529533, 1981.

BRUNK UT, TERMAN A: Lipofuscin: mechanisms of age-related accumulation and influence on cell function. Free Radic Biol Med 33: 611-619, 2002a.

BRUNK UT, TERMAN A: The mitochondrial-lysosomal axis theory of aging: accumulation of damage mitochondria as a result of imperfect autophagocytosis. Eur J Biochem 269: 1996-2002, 2002b.

CSALLANY AS, ZASPEL BJ, AVAZ KL, SPALLHOLZ JE: Selenium and aging. In: Signal Transduction and Cardiac Hypertrophy. JE SPALLHOLZ, JL MARTIN, HE GANTHER (eds), Avi Publishing Company, Westport, Connecticut 1981, pp 118-131.

CSALLANY AS, AVAZ KL, MENKEN BZ: Organic solvent soluble lipofuscin pigments and glutathione peroxidase in weanling and old rats. Int J Vitam Nutr Res 56: 143-147, 1986.

DE GRITZ, RAHKO T, KORPELA H: Diet-induced lipofuscin and ceroid formation in growing pigs. J Comp Pathol 110: 11-24, 1994.

DEL ROSO A, DE TATA V, GORI Z, BERGAMINI E: Transmural differences of lipofuscin pigment accumulation in the left ventricule of rat heart during growth and aging. Aging 3: 19-23, 1991.

GAO G, OLLINGER K, BRUNK UT: Influence of intracellular glutathione concentration of lipofuscin accumulation in cultured neonatal rat cardiac myocytes. Free Radic Biol Med 16: 187-194, 1994.

GOLDSTEIN BD, MCDONAGH EM: Spectrofluorescent detection of in vivo red cell lipid peroxidation in patients treated with diaminodiphenylsulfone. J Clin Invest 57: 1302-1307, 1976.

IKEDA H, TAUCHI H, SHIMASAKI H, UETA N, SATO T: Age and organ difference in amount and distribution of autofluorescent granules in rats. Mech Ageing Dev 31: 139-146, 1985.

KOMATSU M, WAGURI S, UENO T, IWATA J, MURATA S, TANIDA I, EZAKI J, MIZUSHIMA N, OHSUMI Y, UCHIYAMA Y, KOMONAMI E, TANAKA E, CHIBA T: Impairment of starvation-induced and constitutive autophagy in Atg7-deficient mice. J Cell biol 169: 425-434, 2005.

KUMA A, HATANO M, MATSUI M, YAMAMOTO A, NAKAYA H, YOSHIMORI T, OHSUMI Y, TOKUHISA T, MIZUSHIMA N: The role of autophagy during the early neonatal starvation period. Nature 432: 1032-1036, 2004.

LI F, WANG X, CAPASSO JM, GERDES AM: Rapid transition of cardiac myocytes from hyperplasia to hypertrophy during postnatal development. J Mol Cell Cardiol 28: 1737-1746, 1996.

MARZABADI MR, SOHAL RS, BRUNK UT: Mechanisms of lipofuscinogenesis: effect of the inhibition of lisosomal proteinases and lipases under varying concentration of ambient oxygen in cultured rat neonatal myocardial cells. APMIS 99: 416-426, 1991.

MUSCARI C, CALDARERA CM, GUARNIERI C: Age dependent production of mitochondrial hydrogen peroxide, lipide peroxides and fluorescent pigments in the rat heart. Basic Res Cardiol 85: 172-178, 1990.

MÜHLFELD C, SINGER D, ENGELHARDT N, RICHTER J, SCHMIEDL A: Electron microscopy and microcalorimetry of the postnatal rat heart (Rattus norvegicus). Comp Biochem Physiol 141: 310-318, 2005.

OKAMOTO T, MIZUTA K, TAKAHASHI T, KISHI T, KITAHARA S, KOMORI S, HASHIMOTO K, GOSHIMA $\mathrm{K}$ : Protective effect of $\gamma$-glutamylcysteinylethyl ester on dysfunction of the selenium-deficient rat heart. Biochem Pharmacol 57: 955-963, 1999. 
OŠŤÁDAL B, WACHTLOVÁ M, BÍLÝ J, RAKUŠAN K, POUPA O: Weight of the heart in the rat before and after birth. Physiol Bohemoslov 16: 111-115, 1967.

OŠŤÁDALOVÁ I, KOLÁŘ F, OŠŤÁDAL B, ROHLÍČEK V, ROHLÍČEK J, PROCHÁZKA J: Early postnatal development of contractile performance and responsiveness to $\mathrm{Ca}^{2+}$, verapamil and ryanodine in the isolated rat heart. J Mol Cell Cardiol 25: 733-740, 1993.

OŠŤÁDALOVÁ I, VOBECKÝ M, CHVOJKOVÁ Z, MIKOVÁ D, HAMPL V, WILHELM J, OŠŤÁDAL B: Selenium protects the immature heart against ischemia/reperfusion injury. Mol Cell Biochem 300: 259-267, 2007.

SCHAFER FQ, BUETTNER GR: Redox environment of the cell as viewed through the redox state of the glutathione disulfide/glutathione couple. Free Radic Biol Med 30: 1191-1212, 2001.

SOHAL RS, MARZABADI MR, GALARIS D, BRUNK UT: Effect of ambient oxygen concentration on lipofuscin accumulation in cultured rat heart myocytes - a novel in vitro model of lipofuscinogenesis. Free Radic Biol Med 6: 23-30, 1989.

ŠKÁRKA L, BARDOVÁ K, BRAUNER P, FLACHS P, JARKOVSKÁ D, KOPECKÝ J, OŠŤÁDAL B: Expression of mitochondrial uncoupling protein 3 and adenine nucleotide translocase 1 genes in developing rat heart: putative involvement in control of mitochondrial membrane potential. J Mol Cell Cardiol 35: 321-330, 2003.

TERMAN A, BRUNK UT: Autophagy in cardiac myocyte homeostasis, aging, and pathology. Cardiovasc Res 68: 355 366, 2005a.

TERMAN A, BRUNK UT: The aging myocardium: roles mitochondrial damage and lysosomal degradation. Heart Lung Circ 14: 107-114, 2005b.

WILHELM J, HERGET J: Hypoxia induces free radical damage to rat erythrocytes and spleen: analysis of the fluorescent end-products of lipid peroxidation. Int J Biochem Cell Biol 31: 671-681, 1999. 